\title{
PARTICIPATIVE MANAGEMENT STYLE AND ITS RELATION TO EMPLOVEE WILLINGNESS TO ACCEPT JOB OFFER IN THE SAME COMPANY ONCE AGAIN
}

Participative management style is based on the involvement of employees in decision-making and problem-solving in the company, as well as on supporting their high autonomy and own initiative. The article describes outcomes of the research which examines the interaction between the management style and willingness of employees to accept job offer in the current company once again if they were asked in the future. Results confirmed that there is highly significant correlation between the belief of employees they would accept the job offer in the same enterprise again and their satisfaction with current management style as well as use of the elements of participative management style.

Keywords: Participative management style, manager, demotivation, job offer, decision - making.

\section{Introduction}

Participative management style is not a new style of management. It was presented in the book of American professor Douglas McGregor - The Human Side of Enterprise in 1960, which is a classic piece of company bureaucracy and human nature research. McGregor described two different approaches to the management of people: Theory $\mathrm{X}$ and $\mathrm{Y}$ : $\mathrm{X}$ theory which says that the average person has an innate aversion to work and tries to avoid it as much as possible, and because of this innate reluctance should be mostly forced to work, managed, controlled, and sometimes it is necessary to threat employees with penalties to begin to spend adequate effort leading to the achievement of business objectives. Theory Y assumptions say the contrary, that external control and the punishment of employees are not the only possibilities to achieve business goals. In order to accomplish the tasks, one is able to learn self-control and selfmanagement. Commitment to achieving goals depends on the rewards connected to their attainment. The most interesting of these rewards - the satisfaction of the ego and the need for self - realization may be a direct result of efforts to achieve business objectives. In terms of modern industrialized life, the possibilities of the intellect of the average person are only partially used [1].

The current work environment is too bureaucratic and hierarchical, very often with lack of proper management. Business is too focused on the fact that people should not do any mistakes, rather than support them in achieving exceptional results. Superiors treat employees like children who do not think by themself and do not understand anything. Each activity must be approved by several superiors, each activity must be documented carefully. The rules are therefore adjusted so that no one has to do nothing wrong - but even nothing exceptional. In other words, the current model of people management in most companies does not stimulate innovations and the search for higher value-added [2].

The behavior of managers to employees is the factor that has the greatest impact on employee motivation. Managerial behavior leading to demotivation is in most cases unnecessary not related to the "objective" conditions of work. It is the result of management mistakes and mostly of the lack of attention devoted to business training and selection of executives [3].

\section{Participative management style}

In this article we examine the participatory management style that in some companies has the form of so - called freedom at work. According to research studies, the concept of participative management style is currently used by $3-5 \%$ of enterprises only [4], which due to its effectiveness is considered to be too low.

Participative style can be defined as a management style based on informing employees about important aspects of business development and their participation in decision-making and solving business problems, especially those that concern them. The main aim is to use their potential, knowledge, motivation, increase their job satisfaction and strengthen their identification with the company, but at the same time to gain their understanding of the new measures or changes in the company [5].

Participative style does not mean that a manager requests subordinates ideas and opinions, which are then used for decision-making. Participative decision goes further - employees are involved to participate in the management and development of the company, where openness, trust, consensus - building and

\footnotetext{
* Monika Rolkova

Department of Economics, Faculty of Operation and Economics of Transport and Communications, University of Zilina, Slovakia,

E-mail: monika.rolkova@fpedas.uniza.sk
} 
mutual respect are the norms [6]. Subordinates have enough space to present their own initiative and independence in carrying out tasks. The manager encourages participation in decisionmaking of subordinates.

Currently, there are companies in which participative style goes even further - nothing is required, employees can decide what, when, where and how they will do. They can decide when to work, determine the amount of their salary, and elect their own bosses. These companies are usually the leaders in their respective fields of business and are the examples of one of the strongest trend in today's business world. The best examples of freedom at work are companies: Google, Semco, Zappos, W.L.Gore \& Associates, Harley \& Davidson or Martinus in Slovakia. In the free enterprises it is important to have two-way communication, where most decisions are taken by consensus (the right side of continuum in Fig. 1).

Autocratic manage Democratic manager

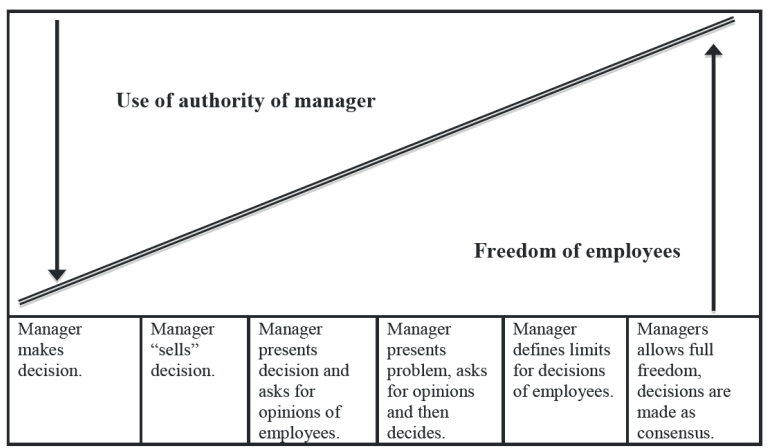

Fig. 1 The Management Behaviour Continuum. Source: self-processed based on [7]

The organization World Blu, which brings together free companies, provides 10 principles of organizational democracy, by which it assesses its members [8]:

1. Purpose and Vision - A democratic organization is clear about why it exists (its purpose) and where it is headed and what it hopes to achieve (its vision). These act as its true North, offering guidance and discipline to the organization's direction.

2. Transparency-stops the "secret society" mentality. Democratic organizations are transparent and open with employees about the financial health, strategy, and agenda of the organization.

3. Dialogue + Listening - Instead of the top - down monologue or dysfunctional silence that characterizes most workplaces, democratic organizations are committed to having conversations that bring out new levels of meaning and connection.

4. Fairness + Dignity - Democratic organizations are committed to fairness and dignity, not treating some people like "somebodies" and other people like "nobodies."

5. Accountability - Democratic organizations point fingers, not in a blaming way but in a liberating way. They are clear about who is accountable to whom and for what.
6. Individual + Collective - In democratic organizations, the individual is just as important as the whole, meaning employees are valued for their individual contribution as well as for what they do to help achieve the collective goals of the organization.

7. Choice - Democratic organizations thrive on giving employees meaningful choices.

8. Integrity - Integrity is the name of the game, and democratic companies have a lot of it. They understand that freedom takes discipline and also doing what is morally and ethically right.

9. Decentralization - Democratic organizations make sure power is appropriately shared and distributed among people throughout the organization.

10. Reflection + Evaluation - Democratic organizations are committed to continuous feedback and development and are willing to learn from the past and apply lessons to improve the future.

According to our prediction based on literature review, participative management style and democracy at work lead to better employee performance. Several studies support this opinion. The studies for example confirmed that satisfied employees are more likely to have low absenteeism and low turnover [9 and 10] Petty, McGee and Cavender in 1984 based on meta - analysis, demonstrated a strong relationship between job satisfaction and employee performance [11]. The findings of multiple regression analysis show that managers 'use of participative management style is positively associated with high levels of job satisfaction [11].

\section{Methodology}

The type of research used in our study is a mapping research. It is a research project to describe and classify the investigated phenomena. This type of quantitative research doesn't require the formulation of scientific hypotheses, but the researcher should formulate the research questions [12].

We decided to focus attention on exploring elements of management style, which is a causal variable applied to business productivity. The main aim of the research was to explore how the elements of management style influences the satisfaction of subordinates. In this article we present two research questions from the study only.

As the research sample, we chose employees on subordinate positions in large international enterprises. We obtained respondents by intentional selection from the following sectors: electricity, gas and telecommunications. Selected companies are long-term existing enterprises in the market and the management of human capital is at a very high level there. We chose them because we wanted to focus the research on companies where human capital management don't deal with the basic problems but it is quite well developed already.

The basic research sample was 39200 employees of selected sectors - according to information from Statistical Office of the Slovak Republic. The selected sample was calculated by Sample 
Size Calculator - free online tool of Creative Research Systems For calculation of sample size we use confidence level of $95 \%$.

All of 200 respondents (Table 1) who filled in the questionnaire work currently on below manager level positions. As a research tool, we decided to use the questionnaire because of the necessary number of respondents and the importance of anonymity needed for examining sensitive issues in the manager - subordinate relationship. In our research we tried to obtain information through a questionnaire of attitudes and opinions on the behavior of their managers. The questionnaire was distributed online the link to webpage with questionnaire was sent via e-mail. The response rate was approximately $50 \%$. We cannot confirm the exact number of employees that got the questionnaire because of snowball technique of targeting respondents - employees that were contacted by us, sent the questionnaire to their colleagues etc.

We created the items in the questionnaire based on literature findings about participative management style and measured them on a four - point Likert type scale (yes - rather yes - rather no no). For statistical testing we used the Kendall's Tau correlation coefficient $b$ - results are shown in Table 2 below.

As potentially problematic aspects in our research can be perceived difficult generalisation on the population of all employees in enterprises in Slovakia due to specific research sample of utilities selected by non-probability sampling. Another limitation is using of questionnaire as a research tool - for example the same sense of each question for all respondents can be a possible problem.

\section{Results}

Research question Q1: Is the satisfaction of employees with management style related to their willingness to accept the job offer in the same company again?

(Correlation of questions: "Would you accept a job offer in this company again?" and "Are you satisfied with the management style used by your manager?”)

Research question Q2: Is the use of elements of participative management style related to willingness of employees to accept the job offer in the same company again?

(Correlation of question: "Would you accept a job offer in this company again?" and total of 15 items in the questionnaire that represents participatory management style - for example level of control, opportunity for own initiative and creativity, autonomy in decision - making, motivation, trust, use of employee potential etc.)
Respondents (non - management employees)

Table 1.

\begin{tabular}{|l|l|l|}
\hline Gender & Amount & $\%$ \\
\hline Man & 96 & 48.0 \\
\hline Woman & 104 & 52.0 \\
\hline Total & 200 & 100.0 \\
\hline
\end{tabular}

Source: self-processed

Correlation is significant at the significance level of 0.01 , which means that:

> the willingness to accept job offer in the same company was positively associated with subordinate satisfaction with the management style,

$>$ the willingness to accept job offer in the same company again in the future was positively associated with the level of managers' use of participative management style.

In this case, we confirm the theoretical prediction that management style is an important factor that affects subordinates, as research results show, it is closely related to whether the subordinates would accept the job offer in the same company again. The results show that the employees who believe in managers' use of participative management style report higher level of willingness to accept an offer to work in the company again.

\section{Conclusion}

This study examined the influence of management style on employee willingness to accept the job offer in the same company again and the relationship between use of participative management style and employee willingness to accept the job offer again. It demonstrated highly positive relationship between the variables.

Several limitations of the research should be noted. The sample size is small but we believe that similar results would be confirmed even in a larger sample. We must admit that the snowball technique is not the most representative way of choosing respondents either.

In practice, we often see the resistance of managers towards participative management style as they believe that if they focus on people development and facilitating their independence, their performance will suffer. We incline to the view that human

\begin{tabular}{|c|c|c|c|c|}
\hline \multicolumn{2}{|c|}{} & Management style & Participative management style \\
\hline $\begin{array}{c}\text { Kendall's } \\
\text { tau_b }\end{array}$ & $\begin{array}{c}\text { Accepting of job offer in the } \\
\text { same company }\end{array}$ & Correlation coefficient &, $564^{* *}$ &, $596^{* *}$ \\
\cline { 3 - 5 } & & $\mathrm{p}$ & .000 & .000 \\
\hline
\end{tabular}

Source: self-processed 
resources are the most important means to achieve results The company cannot be successful without the financial and material resources, but human resources should be an active element that sets the other ones in motion and keep them going. The difference is, whether the performance is achieved by encouraging co - operation and activities of the human factor, it means "with people" or "against them". An effective manager has the highest performance due to effective leading style. He uses individual motivation, reinforces the sense of group loyalty and identification with the organization. The ideal situation is when maximum performance is accompanied by employee satisfaction, good relationships within the group and a positive team spirit at work [13]. Researches show that satisfied employees are more productive in the long run than unhappy and dissatisfied. They don't have so many absences, are less likely to leave the company and work more than what their duties are. Our research aimed to contribute to a deeper knowledge of the attributes and relations of participative management style. We confirmed that the willingness of employees to accept the job offer in the same company again is significantly related to their satisfaction with management style, as well as using of elements of participative management style. We consider this style as the most appropriate style of management for the future of business. The companies should consider including participative management and employee empowerment techniques as components of management development and education programs.

\section{References}

[1] CARNEY, B. M., GETZ, I.: Freedom at Work (in Czech), Praha: PeopleComm, 2011. ISBN 978-80-904890-1-1.

[2] URIGA, J.: How the Work Will Look Like in Ten Years (in Slovak), Trend, 12.5.2011, pp.14-17. ISSN 1336-2674.

[3] URBAN, J.: How to Prevent Employee Demotivation (in Czech), Human Resources Management, No. 4, 2011 , pp. 31. ISSN 1801-4690.

[4] Management Study Guide: A Basic Understanding of Participative Management. 2012, [online]: <http://www.managementstudyguide. com/participative-management.htm>

[5] URBAN, J.: Goals and Methods of Employee Participation (in Czech), Mzdy \& personalistika v praxi, No. 7, 2005. [online] cit. 1.8.2012: 〈http://www.mzdovapraxe.cz/archiv/dokument/doc-d1193v1169-cile-a-metody-zamestnanecke-participace/>.

[6] JINDRA, J.: Management Alphabet - Participative Management Style (in Czech), Metodicky portal RVP 3.11.2008, [online] cit. 7.7.2012: 〈http://clanky.rvp.cz/clanek/s/Z/2743/ABECEDA-MANAGEMENTU-PARTICIPATIVNI-STYL-RIZENI.html/ >.

[7] CEJTHAMR, V., DEDINA, J.: Management and Organizational Behaviour (in Czech), Praha: Grada Publishing 2010. ISBN 97880-247-3348-7.

[8] WORLD BLU: 10 Principles of Organisational Democracy. World Blu, 2012, cit. 30.6.2012, [online]: <http://www.worldblu.com/ democratic-design/principles.php>.

[9] EBY, L.T., FREEMAN, D.M., RUSH, M.C., LANCE, C.E.: Motivational Bases of Affective Organizational Commitment: A Partial Test of an Integrative Theoretical Model, J. of Occupational and Organizational Psychology, vol. 72, 1999, pp. 463-483, ISSN: 2044-8325.

[10] PIERCE, J. L., RUBENFELD, S. A., MORGAN, S.: Employee Ownership: A Conceptual Model of Process and Effect, Academy of Management Review, vol. 16, 1991, pp. 121-144, ISSN 0363-7425.

[11] KIM, S.: Participative Management and Job Satisfaction: Lessons for Management Leadership, Public Administration Review, No. 3-4, 2002, pp. 231-241, ISSN 1540-6210.

[12] PAVLICA, K.: Social Research, Company and Management (in Czech), Praha : Ekopress, 2000. ISBN 80-86119-25-4.

[13] STEPANIK, J.: The Most Often Mistakes and Failures of Managerial Praxis (in Czech), Praha: Grada Publishing, 2010. ISBN 978-80-247-2494-2. 